\title{
Response of Four New Bread Wheat (Triticum aestivum L.) Cultivars to Nitrogen Fertilizer Levels under Sprinkler Irrigation System in Sandy Soils
}

\section{I.M. Abd El-Hameed}

Department of Agronomy, Faculty of Agriculture, Zagazig

University, Sharkia, Egypt.

\begin{abstract}
7 WO FIELD experiments were carried out in the Experimental Farm of Faculty of Agriculture in El-Khattara Region, Zagazig University, Egypt during two successive winter seasons (2009/2010 2010/2011). The experiments aimed to study the response of some new bread wheat cultivars (Egypt 1, Sakha 94, Sids 12 and Sids 13) to nitrogen fertilizer levels (50, 75 and $100 \mathrm{~kg} \mathrm{~N} / \mathrm{fed})$ under sprinkler irrigation in sandy soils.

Results could be summarized as follows:

1-Significant differences were detected among the four wheat cultivars in all studied characters during the two seasons and their combined analysis. Where, wheat cultivar Sids 13 followed by Sids 12 and Egypt 1 recorded the highest values regarding spike length $(\mathrm{cm})$, number of spikelets per spike, number of grains per spike, grain weight (gm) per spike and grain yield (ardab per fed), while wheat cultivar Sakha 94 gave the lowest values in all aforementioned traits except plant height in both seasons and their combined analysis.

2- The increase of $\mathrm{N}$ level from 50 to 75 and up to $100 \mathrm{~kg} \mathrm{~N} / \mathrm{fed} \mathrm{led} \mathrm{to}$ significant increase in aforementioned characters in both seasons and their combined analysis.

3- Grain yield reached its maximum values, i.e. 11.4 and 11.8 ardab per fed when plants were fertilized with 112.5 and $93.6 \mathrm{~kg} \mathrm{~N}$ per fed for both wheat cultivars Sids 12 and Sids 13,respectively. The results, further indicated that, optimum yields were 10.83 and 11.74 ardab per fed and could be obtained when 75 and $78.9 \mathrm{~kg} \mathrm{~N}$ per fed were added for both wheat cultivars Sids 12 followed by Sids 13 , respectivley.
\end{abstract}

Keywords: Wheat, Cultivars, Nitrogen, Sprinkler irrigation , Sandy soils.

Bread wheat (Triticum aestivum L.) is considered to be one of the most important cereal crops in the world as well as in Egypt (FAO, 2007). In Egypt, the national production of cereals is relatively lower than the consumption demands. Raising wheat production through increasing the productivity per area unit is the most important national target to minimize the gap between the 
Egyptian production and annual local demand. Improving productivity could be achieved by cultivating high yielding cultivars coupled with improved agronomic practices such as nitrogen fertilizer application. Many workers showed that wheat cultivars differ in yield and yield components. Ashmawy \& Abo-Warda (2002) showed that wheat cv. Giza-168 significantly surpassed Sids1 and Gemmeiza-9 cultivars in grain yield per fed, number of grains per spike and 1000-grain weight, Moreover, Abd El-Hmeed (2005) concluded that, wheat cultivar Giza-168 gave higher values of number of spikelets per spike, number of grains per spike, 1000-grain weight and grain yield per fed than Sakha-93 one. Gafar (2007), Ramadan \& Awaad (2008) and El-Murshedy (2008) stated that, the varietals differences significantly affected plant height, spike length, number of spikelets and grains per spike, grain weight per spike and grain yield per fed. Zeidan et al. (2009) stated that, significant differences were detected among three wheat cultivars, where, Sids 1 was superior and gave the highest values per no. of grains per spike, grain weight per spike, 1000grain weight and grain yield per fed followed by Giza 168 ,while Sakha 93 produced the lowest values in all studied chracters. However, Amin et al. (2010) reported that, wheat cultivar Gemmeiza 9 gave the highest number and heaviest grains per spike and grain yield followed by Sakha 93 and Giza 168. On the contrary, Saleh (2003) did not find any effect of varietal differences on grain yield per feddan.

Nitrogen plays an important role in plant life and is considered an indispensable element for several vital functions. Abd El-Hmeed \& Omar (2006) concluded that, increasing $\mathrm{N}$ level up to $105 \mathrm{~kg}$ N/fed significantly increased each of spike length, number of spikelets and grains per spike, 1000-grain weight and grain yield per fed. Shaaban (2006) reported significant increase in grain yield per fed of wheat grown under sandy soil conditions due to the increase of $\mathrm{N}$ level up to $40 \mathrm{~kg}$ per fed with organic nitrogen addition. Gafar (2007) found that no. of spikelets and grains per spike, 1000- grain weight and grain yield responded to the increase of $\mathrm{N}$ level up to $60 \mathrm{~kg} \mathrm{~N}$ per fed while, plant height responded to $90 \mathrm{~kg} \mathrm{~N}$ per fed. Weber et al. (2008) pointed out that the increase of $\mathrm{N}$ level up to $180 \mathrm{~kg}$ per hectare $(75.6 \mathrm{~kg} \mathrm{~N}$ per fed) was effective to increase grain yield per ha. Ahmed et al. (2009) reported that, doubling the level of added $\mathrm{N}$ to $100 \mathrm{~kg}$ per fed was accompanied by a significant increase in plant height, no. of spikelets and grains per spike,1000- grain weight and grain yield per fed. Zeidan et al. (2009) stated that, increasing $\mathrm{N}$ fertilizer level up to $120 \mathrm{~kg}$ per fed significantly increased no. of grains per spike, grain weight per spike, 1000grain weight and grain yield per feddan.

The present investigation aimed to study the response of some new bread wheat cultivars (Egypt 1, Sakha 94, Sids 12 and Sids 13) to nitrogen fertilizer levels $(50,75$ and $100 \mathrm{~kg} \mathrm{~N}$ per fed) in sandy soil conditions under sprinkler irrigation system.

Egypt. J. Agron. 34, No. 1 (2012) 


\section{Materials and Methods}

Two field experiments were carried out in the Experimental Farm of Faculty of Agriculture, Zagazig University, in the El-Khattara Region, Sharkia Governorate, Egypt during two winter successive seasons (2009/2010 2010/2011). The experiment aimed to study the response of some bread wheat (Triticum aestivum L.) cultivars (Egypt 1, Sakha 94, Sids 12 and Sids 13) to nitrogen fertilizer levels (50,75 and $100 \mathrm{~kg} \mathrm{~N}$ per fed) in sandy soil conditions under sprinkler irrigation system. The experimental field soil was sandy in texture, had an average $\mathrm{pH}$ value of $7.7 ; 0.51$ organic matter and had 12.5, 3.4 and $132 \mathrm{ppm}$ available $\mathrm{N}, \mathrm{P}$ and $\mathrm{K}$, respectively (averaged over of the two seasons for the upper $30 \mathrm{~cm}$ of soil depth). Each experiment included 12 treatments which were the combination of four bread wheat cultivars (Egypt 1, Sakha 94, Sids 12 and Sids 13) and three levels of nitrogen fertilizer (50,75 and $100 \mathrm{~kg} \mathrm{~N}$ per feddan).

A split- plot design with three replicates was followed, cultivars were assigned to the main plots, whereas, nitrogen fertilizer levels were allocated in the sub plots. The area of plot was $5.0 \mathrm{~m}^{2}$ ( $2.5 \mathrm{~m}$ in length and $2.0 \mathrm{~m}$ in width) included 10 rows, $20 \mathrm{~cm}$ apart. Seeds (450 grains per $\mathrm{m}^{2}$ ) were hand drilled on December $10^{\text {th }}$ and $14^{\text {th }}$ in the first and second seasons, respectively. Phosphorous fertilizer was applied during soil preparation in the form of calcium super phosphate $\left(15.5 \% \quad \mathrm{P}_{2} \mathrm{O}_{5}\right)$ with $31.0 \mathrm{~kg} \mathrm{P}_{2} \mathrm{O}_{5}$ per feddan, other normal cultural practices of wheat were applied properly as recommended for the region.

\section{Response to nitrogen fertilization}

The present study seeks to find out the differential response of the four newly released bread wheat cultivars to $\mathrm{N}$ fertilizer levels. Significance of four cultivars response to $\mathrm{N}$ increments and the significant $\mathrm{NxCvs}$ interactions were calculated according to Snedecor \& Cochran (1981), using the orthogonal polynomial Tables. Significance of the linear and quadratic components of each of the equations was tested and hence the response could be described as linear (first order) or quadratic (second order). The predicted maximum $\left(\mathrm{Y}_{\max }\right)$ and optimums $\left(\mathrm{Y}_{\mathrm{opt}}\right)$ of grain yields, as well as, the predicted maximum $\left(\mathrm{X}_{\max }\right)$ and optimum $\left(X_{\text {opt }}\right)$ N levels were calculated according to Sukhatme (1941), as follows:

$\mathrm{Y}^{\wedge}=\mathrm{a}+\mathrm{bx}-\mathrm{cx} 2 \quad \mathrm{Y}_{\mathrm{opt}}^{\wedge}=\mathrm{Y} 0+(\mathrm{b}-\mathrm{r}) 2 / 4 \mathrm{c},\left(\mathrm{X}_{\max }\right)=\mathrm{X}_{0}+\mathrm{b} / 2 \mathrm{c}(\mathrm{u})$.

$\mathrm{X}_{\text {opt }}=\mathrm{X} 0+\mathrm{b}-\mathrm{r} / 2 \mathrm{c}(\mathrm{u}) \quad \mathrm{Y}_{\max }=\mathrm{Y}_{0}+\mathrm{b} 2 / 4 \mathrm{c}$.

where: $\mathrm{Y}_{0}=$ Grain yield at the lowest $\mathrm{N}$ level (X0) i.e. $50 \mathrm{~kg} \mathrm{~N} / \mathrm{fed}$ (ardab / feddan).

$\mathrm{b}=$ Measures the linear components of the response equation.

$\mathrm{c}=$ Measures the quadratic components of the response equation.

$\mathrm{r}=\mathrm{q} / \mathrm{p} \quad \mathrm{q}=$ Cost of $\mathrm{N}$ unit (u) i.e. $50 \mathrm{~kg} \mathrm{~N} / \mathrm{fed}=120.0$ L.E.

$\mathrm{p}=$ Price of a unit yield $(\operatorname{ardab})=400$ L.E.

$\mathrm{u}=$ The interval between levels of $\mathrm{N}$ 
For all characters under study the predicted maximum averages which could have been obtained if the $\mathrm{N}$ level was increased to a certain maximum, i.e. $\mathrm{X}_{\text {max }}$. were also calculated in order to define the yield limiting components.

The studied cultivars used were: 1-Egypt 1, 2-Sakha 94, 3-Sids 12, 4-Sids 13. Nitrogen in form of ammonium sulfate $(20.5 \% \mathrm{~N})$ was supplied in seven equal doses at 10, 20, 30, 40, 50, 60 and 70 days after sowing. Wheat was sown after a fallow in the two seasons. A fixed rate of $50 \mathrm{~kg} \mathrm{~K}_{2} \mathrm{O}$ per feddan of potassium sulphate $\left(48 \% \mathrm{~K}_{2} \mathrm{O}\right)$ was given in equal portions at sowing and heading. Sprinkler irrigation was scheduled at an almost one week interval during winter and this period was shortened to four or five days from the beginning of spring up to fifteen days before harvest. Harvest was done during the last week of April in the first and second seasons. Sample of ten guarded plants were taken from each plot to measure: (1) Height of wheat plant (from soil surface up to spike tip), ten spikes were randomly selected from each treatment to measure. (2) Spike length $(\mathrm{cm})$. (3) Number of spikelets per spike. (4) Number of grains per spike. (5) Grain weight per spike (g). (6) Thousand grain weight $(\mathrm{g})$, the inner seven rows of each sub- plot by a long of $1.5 \mathrm{~m}$ $\left(2.10 \mathrm{~m}^{2}\right)$ were harvested to determine. (7) Grain yield (ardab per feddan).

Statistical analysis of each experiment was performed as the methods outlined by Steel \& Torrie (1980). Significancy of differences between the various means of different characters under study was compared with the help of Duncan's multiple range test (1955). In the interaction tables, capital and small letters were used for the comparison among rows and columns means, respectively.

\section{Results and Discussion}

\section{Plant height (cm), spike length $(\mathrm{cm})$ and number of spikelets per spike Effect of cultivar}

Results presented in Table 1 show that, plant height, spike length and number of spikelets per spike of the four wheat cultivars in both seasons and their combined were affected by cultivars. It was evident (from the- combined analysis) that wheat cultivar Sids 13 surpassed in spike length $(9.66 \mathrm{~cm})$ and number of spikelets per spike (16.53) the other three cultivars (Sids 12 , Egypt 1 and Sakha 94). Meanwhile, wheat cultivar Sakha 94 produced the lowest values $(8.45 \mathrm{~cm}$ in spike length and 15.45 spikelet per spike). The differences in plant height were significant where, wheat cultivar Sakha 94 showed the highest values $(83.45 \mathrm{~cm})$ while, the other three wheat cultivars were lowest. The differences in plant height and number of spikelets per spike among the evaluated four wheat cultivars might be attributed to the genetic variations. Similar result was found by Ashmawy \& Abo-Warda (2002), Hassan et al. (2002), Abd El-Hmeed (2005), Zeidan et al. (2005), Gafar (2007), Ramadan \& Awaad (2008), Ahmed et al. (2009) and Amin et al. (2010). 
RESPONSE OF FOUR NEW BREAD WHEAT (TRITICUM AESTIVUM L.).. 5

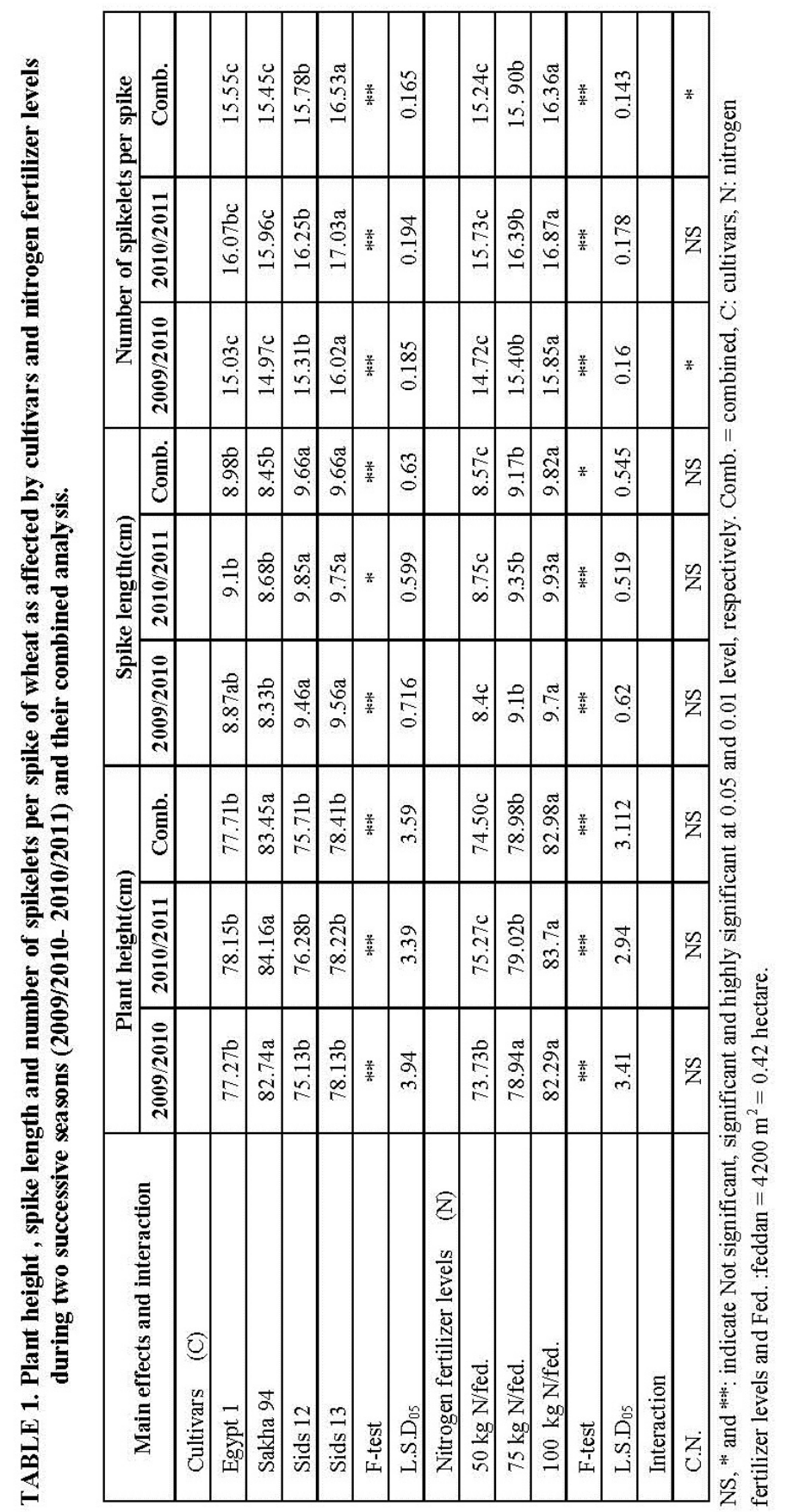

Egypt. J. Agron. 34, No. 1 (2012) 
Effect of nitrogen

Regarding the influence of nitrogen fertilization, the results in Table 1 revealed significant differences between the two seasons and their mean values. Raising nitrogen fertilizer level from 50 to 75 and up to $100 \mathrm{~kg} \mathrm{~N} / \mathrm{fed}$, led to gradual increase in plant height, spike length and number of spikelets per spike of wheat plants. Therefore, the highest values of these traits were achieved by the addition of the highest rate of $\mathrm{N}(100 \mathrm{~kg} \mathrm{~N} / \mathrm{fed})$, while the low rate of $50 \mathrm{~kg} \mathrm{~N}$ per fed resulted in lowest one. The average increase for the mean of both seasons for $1^{\text {st }}$ and $2^{\text {nd }} \mathrm{N}$ - increment reached about 6 and $11.4 \%$ for plant height, 7 and $14.6 \%$ for spike length and 8.1 and $7.7 \%$ for no. of spikelets per spike, respectively. Such increment in plant height, spike length and number of spikelets per spike accompanied with increasing $\mathrm{N}$ level might be attributed to the stimulation of internodes elongation and enhanced growth. The positive role of nitrogen in plant height, spike length and number of spikelets per spike of wheat is extensively reported in the literature where many authors got significant increase in traits due to addition of nitrogen up to $60 \mathrm{~kg} \mathrm{~N}$ per fed. These results are similar with those obtained by Mohamed et al. (2001), Abd El- Hmeed (2005) and Abd El-Hmeed \& Omar (2006) and Ahmed et al. (2009).

\section{Interaction effect}

As shown in the combined analysis, the interaction effect between the four bread wheat cultivars and nitrogen fertilizer levels on number of spikelets per spike were significant (Tables 1 and 1-a). It was quite clear from these tables that addition of $\mathrm{N}$ has increased the response of no. of spikelets per spike to $\mathrm{N}$ increments, this response was linear when $\mathrm{N}$ was added up to $100 \mathrm{~kg} \mathrm{~N}$ per fed for the three cultivars (Sakha 94, Sids 12 and Sids 13) indicating the need for more $\mathrm{N}$ than the highest level tried in this study in order to maximize no. of spikelets per spike for all cultivars. But, this response was quadratic in the number of spikelets per spike when using Egypt 1. There was a significant decrement of -0.645 gram per spike, indicating a significant bending in the response curve. Also, receiving wheat cultivar plants Sids 13 the highest amount of nitrogen dose (100 kg N per fed) gave the highest value of that trait (16.45 spikelet per spike) while, the lowest value (14.23 and 14.4 spikelet per spike) was obtained by the cultivars Egypt 1 and Sakha 94 when plants received the lowest dose of nitrogen $(50 \mathrm{~kg} \mathrm{~N}$ per fed).

\section{Number of grains and its weight per spike $(g)$}

Effect of cultivars

Results presented in Table 2 show that, number of grains per spike and grain weight per spike of the four bread wheat cultivars in both seasons and their combined were significantly different. It was evident that the highest means of the previous characters $(39.67$ grain per spike and 2.13 gram for grain per spike) were obtained by using wheat cultivar Sids 13 when compared with the other cultivars Sids 12, Egypt 1. Meanwhile, wheat cultivar Sakha 94 produced the lowest values (37.37 grain per spike and 1.77 gram for grains per spike). The differences in number of grains per spike and grain weight per spike (g) among the evaluated bread wheat cultivars might be attributed to the genetically variations. Similar results were reported by Ashmawy \& AboWarda (2002), Hassan et al. (2002), Abd El-Hmeed (2005), Tabl et al. (2005), Zeidan et al. (2005), EL-Sawi et al. (2006), Gafar (2007), Ramadan \& Awaad (2008), El-Murshedy (2008), Ahmed et al. (2009) and Amin et al. (2010).

Egypt. J. Agron. 34, No. 1 (2012) 
RESPONSE OF FOUR NEW BREAD WHEAT (TRITICUM AESTIVUM L.)...

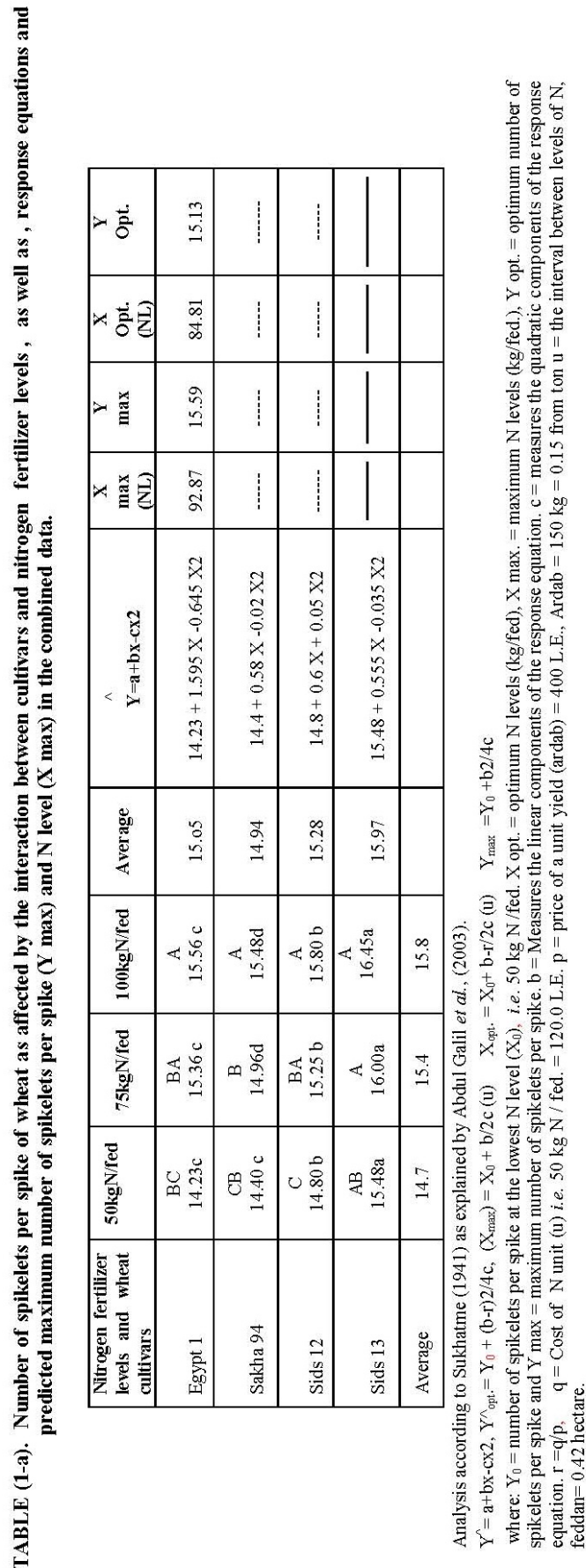

Egypt. J. Agron. 34, No. 1 (2012) 
TABLE 2. Number of grains per spike and grain weight spike of wheat as affected by cultivars and nitrogen fertilizer levels during the two successive seasons $(2009 / 2010$ and $2010 / 2011)$ and their combined analysis.

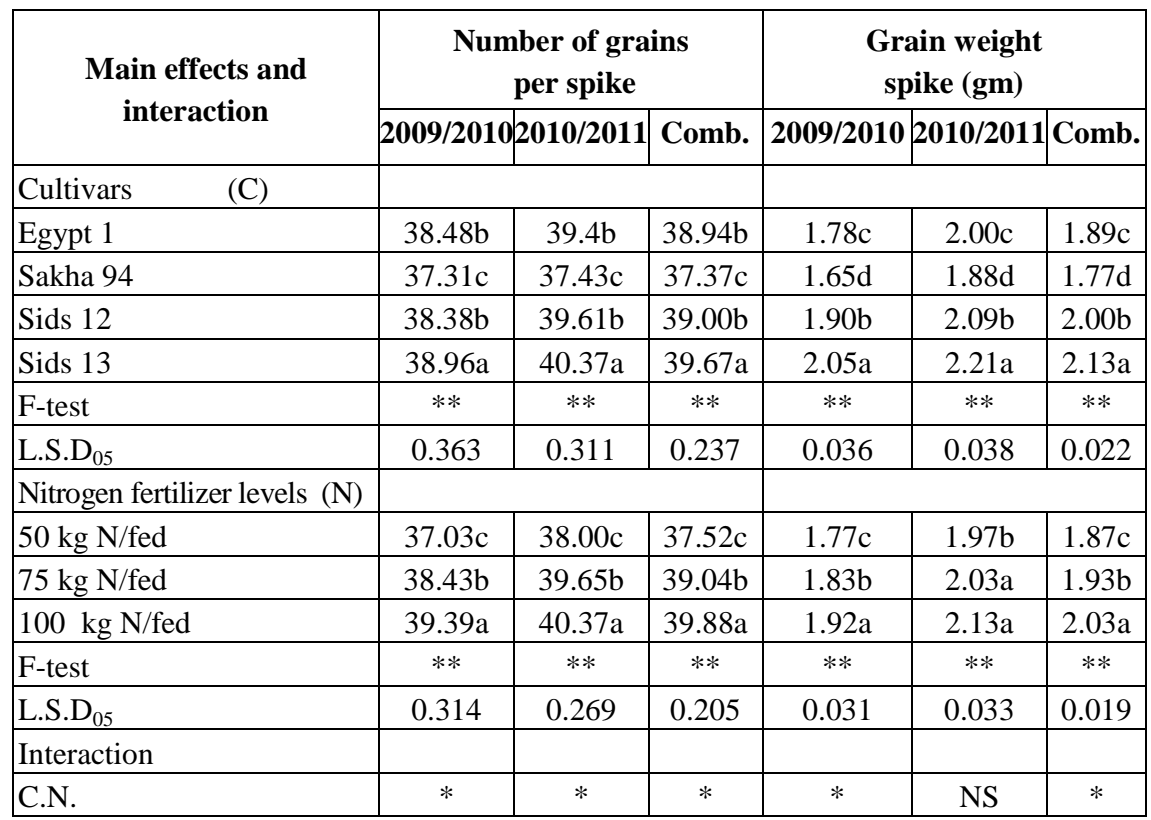

NS, * and **: indicate Not significant, significant and highly significant at 0.05 and 0.01 level, respectively. Comb. $=$ combined, C: cultivars, N; nitrogen fertilizer levels and Fed : feddan $=4200 \mathrm{~m}^{2}$ $=0.42$ hectare.

\section{Nitrogen effect}

Regarding the influence of nitrogen fertilizer levels the results in Table 2 revealed significant differences in the two seasons and the combined analysis. Raising nitrogen fertilizer level from 50 to 75 and up to $100 \mathrm{~kg} \mathrm{~N}$ per fed, led to gradual increase in number of grains per spike and grain weight per spike $(\mathrm{g})$. Therefore, the highest values of number of grains per spike (39.88) and grain weight per spike (2.03 gram) were achieved by addition the highest dose of $\mathrm{N}$ (100 kg N per fed), while the lowest dose of $50 \mathrm{~kg} \mathrm{~N} /$ fed produced the lowest one (37.52 grain per spike and 1.87 weight of grains per spike). The average increase for the mean of both seasons for $1^{s t}$ and $2^{\text {nd }} \mathrm{N}$ - dose reached about 4.6 and $7.0 \%$ for number of grains per spike and 9.0 and $12.2 \%$ for grain weight per spike, respectively. Such increments might be attributed to the positive role of nitrogen in increasing photosynthesis activity which cause more flower fertility and setting per spike, and stimulation the plant capacity in building more metabolites which translocate to develop grains and increase grain weight. Several investigators, came to the same conclusion; included Mohamed et al. (2001) Abd ElHmeed (2005) , Abd El-Hmeed \& Omar (2006) and Ahmed et al. (2009).

Egypt. J. Agron. 34, No. 1 (2012) 


\section{Interaction effect}

Data of the mean of both seasons, show significant interaction effect between the four bread wheat cultivars and nitrogen fertilizer levels on no. of grains per spike and its weight in Tables 2, 2-a and 2-b, respectively. It was quite clear from these tables that addition of $\mathrm{N}$ has increased the response of number of grains and its weight per spike to $\mathrm{N}$ increments, this response was linear when $\mathrm{N}$ was added up to $100 \mathrm{~kg} \mathrm{~N}$ per fed indicating that more $\mathrm{N}$ than the highest level tried in this study is needed in order to maximize number of grains per spike and grain weight per spike for all cultivars. But, this response was quadratic in grain weight per spike when using Sids 12 . There was a significant decrement of -0.045 gram per spike, indicating a significant bending in the response curve. The data indicate that receiving the cultivar Sids 13 the highest amount of nitrogen dose $(100 \mathrm{~kg} \mathrm{~N}$ per fed) produced the highest values of that traits (40.56 grain per spike and 2.09 gram of grains per spike) while, the lowest values (35.73 grain per spike and 1.56 gram of grains per spike) were recorded by the cultivar Sakha 94 which, received the low amount of nitrogen dose (50 kg N/feddan).

1000-grain weight (g) and grain yield (ardab per feddan)

Cultivars effect

Data given in Table 3 clearly indicate that, wheat cultivar Sids 13 produced, the heaviest grains expressed as 1000-grain weight (39.60 gram), and the highest grain yield (11.49 ardab per fed) followed by wheat cultivar Sids 12 and Egypt 1 (38.01 and 37,33 gm and 11.04 and 10.81 ardab per fed for previous traits, respectively. At the same time, wheat cultivar Sakha 94 recorded the lowest means (36.88 $\mathrm{g}$ and 10.13 ardab per fed for previous traits, respectively). The differences in 1000-grain weight (g) and grain yield (ardab per feddan) among the evaluated four wheat cultivars might be attributed to the genetic variations. Similar observations were found by Ashmawy \& Abo-Warda (2002), Hassan et al., (2002), Abd El-Hmeed (2005), Zeidan et al. (2005), Tabl et al. (2005), EL-Sawi et al. (2006), Gafar (2007), El-Murshedy (2008), Ramadan \& Awaad (2008), Ahmed et al. (2009) and Amin et al. (2010) while, Saleh (2003) did not find any effect of varieties on grain yield per feddan.

\section{Nitrogen effect}

Regarding the influence of nitrogen fertilization, the results revealed highly significant differences in the two seasons and their combined analysis. Meanwhile, raising nitrogen fertilizer level from 50 to 75 and up to $100 \mathrm{~kg} \mathrm{~N}$ per fed, increased 1000-grain weight (gm) and grain yield (ardab per fed). Here, it can be noticed that the increase in grain yield (ardab per fed) caused by $\mathrm{N}$ - level of $100 \mathrm{~kg} \mathrm{~N}$ per fed is in accompanied with the increase in spike length and no. of spikelets per spike (Table 1), consequently, no. of grains per spike and grain weight per spike (Table 2) and thousand grain weight (Table 3 ) increased with application of $\mathrm{N}$ up to the highest level tested ( $100 \mathrm{~kg} \mathrm{~N}$ per fed). The average increase for the mean of both seasons for $1^{\text {st }}$ and $2^{\text {nd }} \mathrm{N}$ - increment reached about 0.9 and $3.7 \%$ for thousand grain weight and 4.2 and $6.0 \%$ for grain yield, respectively. These results are in harmony with those obtained by Mohamed et al. (2001), Abd El- Hmeed (2005), Abd El-Hmeed \& Omar (2006), Weber et al. (2008) and Ahmed et al. (2009). 


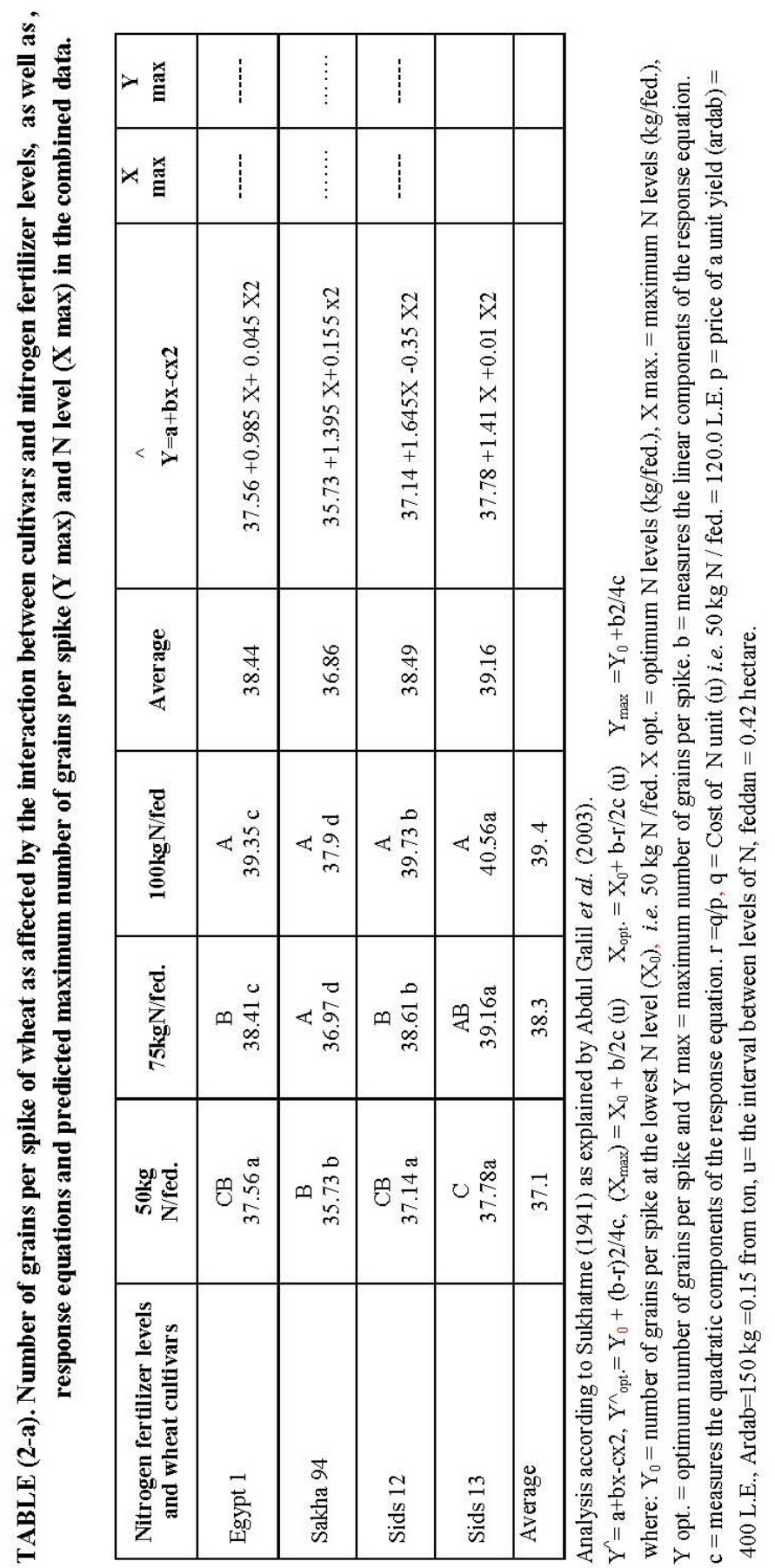

Egypt. J. Agron. 34, No. 1 (2012) 
RESPONSE OF FOUR NEW BREAD WHEAT (TRITICUM AESTIVUM L.)..

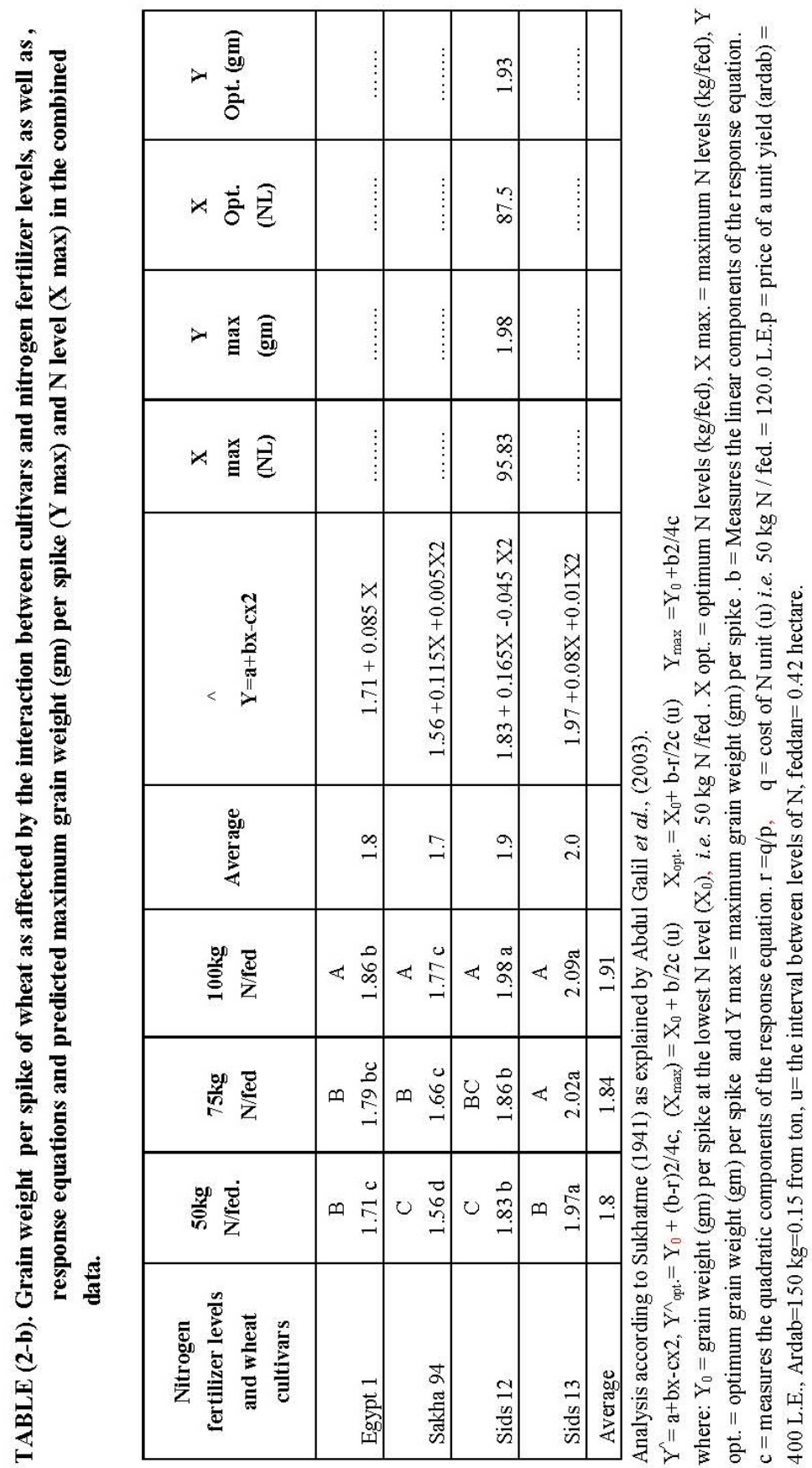

Egypt. J. Agron. 34, No. 1 (2012) 
TABLE 3. 1000-grain weight and grain yield of wheat as affected by cultivars, nitrogen fertilizer levels during the two successive seasons $(2009 / 2010$ and 2010/2011) and their combined analysis.

\begin{tabular}{|c|c|c|c|c|c|c|}
\hline \multirow{2}{*}{$\begin{array}{l}\text { Main effects and } \\
\text { interaction }\end{array}$} & \multicolumn{3}{|c|}{$\begin{array}{l}\text { 1000-grain } \\
\text { weight(gm) }\end{array}$} & \multicolumn{3}{|c|}{$\begin{array}{c}\text { Grain yield } \\
\text { (ardab per fed) }\end{array}$} \\
\hline & $2009 / 2010$ & $2010 / 2011$ & Comb. & $2009 / 2010$ & $2010 / 2011$ & Comb. \\
\hline \multicolumn{7}{|l|}{ Cultivars $\quad(\mathrm{C})$} \\
\hline Egypt 1 & $36.84 \mathrm{c}$ & $37.82 \mathrm{c}$ & $37.33 \mathrm{c}$ & $10.85 b$ & $10.77 \mathrm{c}$ & $10.81 \mathrm{c}$ \\
\hline Sakha 94 & $36.37 d$ & $37.38 \mathrm{~d}$ & $36.88 \mathrm{~d}$ & $9.94 \mathrm{c}$ & $10.32 d$ & $10.13 d$ \\
\hline Sids 12 & $37.62 \mathrm{~b}$ & $38.40 \mathrm{~b}$ & $38.01 \mathrm{~b}$ & $10.99 \mathrm{~b}$ & $11.09 \mathrm{~b}$ & $11.04 \mathrm{~b}$ \\
\hline Sids 13 & $38.90 \mathrm{a}$ & $40.30 \mathrm{a}$ & $39.60 \mathrm{a}$ & $11.54 \mathrm{a}$ & $11.40 \mathrm{a}$ & $11.49 \mathrm{a}$ \\
\hline F-test & $* *$ & $* *$ & $* *$ & $* *$ & $* *$ & $* *$ \\
\hline L.S.D ${ }_{05}$ & 0.404 & 0.278 & 0.266 & 0.154 & 0.169 & 0.118 \\
\hline \multicolumn{7}{|l|}{$\begin{array}{l}\text { Nitrogen fertilizer } \\
\text { levels } \quad(\mathrm{N})\end{array}$} \\
\hline $50 \mathrm{~kg} \mathrm{~N} / \mathrm{fed}$ & $36.76 \mathrm{c}$ & $37.62 \mathrm{c}$ & $37.19 \mathrm{c}$ & $10.53 \mathrm{c}$ & $10.50 \mathrm{c}$ & $10.51 \mathrm{c}$ \\
\hline $75 \mathrm{~kg} \mathrm{~N} / \mathrm{fed}$ & $37.38 \mathrm{~b}$ & $38.45 b$ & $37.92 \mathrm{~b}$ & $10.88 \mathrm{~b}$ & $10.99 \mathrm{~b}$ & $10.95 b$ \\
\hline $100 \mathrm{~kg} \mathrm{~N} / \mathrm{fed}$ & $38.16 \mathrm{a}$ & $39.35 \mathrm{a}$ & $38.76 \mathrm{a}$ & $11.08 \mathrm{a}$ & $11.20 \mathrm{a}$ & $11.14 \mathrm{a}$ \\
\hline F-test & $* *$ & $* *$ & $* *$ & $* *$ & $* *$ & $* *$ \\
\hline L.S.D ${ }_{50}$ & 0.35 & 0.24 & 0.23 & 0.133 & 0.146 & 0.102 \\
\hline \multicolumn{7}{|l|}{ Interaction } \\
\hline C.N. & NS & NS & $*$ & $*$ & $*$ & $*$ \\
\hline
\end{tabular}

NS, $*$ and **: indicate Not significant, significant and highly significant at 0.05 and 0.01 level, respectively. Comb. $=$ combined, $C$ : cultivars, $\mathrm{N}$; nitrogen fertilizer levels and fed : feddan $=4200 \mathrm{~m}^{2}$ $=0.42$ hectare

However, Shaaban (2006) reported significant increase in grain yield per fed of wheat grown under sandy soil conditions due to the increase of $\mathrm{N}$ level up to $40 \mathrm{~kg}$ per fed with organic nitrogen addition.

\section{Interaction effect}

Data of the mean of the two seasons, show significant interaction effect between the four cultivars and $\mathrm{N}$ fertilizer level on 1000-grain weight (Table 3-a) and grain yield (Table 3-b). It was quite clear from these tables that the addition of $\mathrm{N}$ has increased the response of 1000-grain weight to $\mathrm{N}$ increments, this response was linear when $\mathrm{N}$ was added up to $100 \mathrm{~kg} \mathrm{~N}$ per fed for all cultivars indicating the need for more $\mathrm{N}$ than the highest level tried in this study in order to maximize that trait. Also, each $\mathrm{N}$ increment produced a linear increase of $0.12,0.54,0.50$ and 0.82 ardab per fed. for cultivars Egypt 1, Sakha 94, Sids 12 and Sids 13 , respectively and a significant decrement were -0.1 and -0.24 ardab per fed for Sids 12 and Sids 13 , respectively. Hence, high grain yield maximum of 11.4 and 11.8 ardab per fed obtained if high N levels of 112.5 and $93.6 \mathrm{~kg} \mathrm{~N}$ per fed for Sids 12 and Sids 13 , respectively are added. Results, further indicated that, optimum yields were 10.83 and 11.74 ardab per fed could be obtained when 75 and $78.9 \mathrm{~kg} \mathrm{~N}$ per fed were added for Sids 12 and Sids 13 , respectively. It can be seen that planting wheat cultivar Sids 13 which receiving the higher dose of N (100 kg N/fed) gave the higher values of 1000 -grain weight $(40.10 \mathrm{~g})$ as well as grain yield (11.79 ardab per feddan) than those receiving 50 or $75 \mathrm{~kg} \mathrm{~N}$ per feddan whereas, the lower values ( $35.8 \mathrm{~g}$ and 9.6 ardab per fed for previous traits, respectively) were achieved by using the cultivar Sakha 94 when it was fertilized with the $1^{\text {st }}$ dose of $50 \mathrm{~kg} \mathrm{~N}$ per fed (Tables 3, 3-a and 3-b), respectively. 


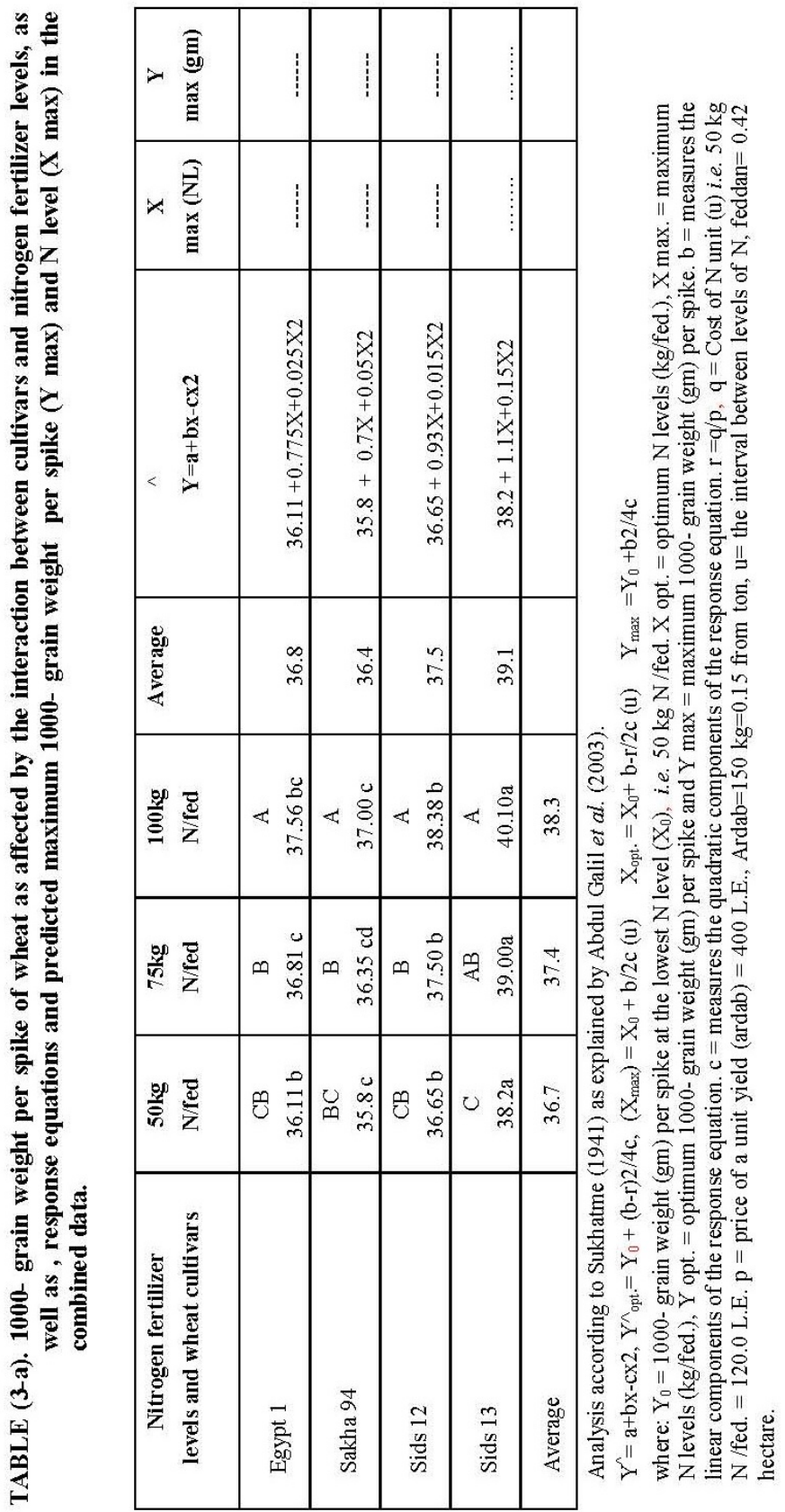

Egypt. J. Agron. 34, No. 1 (2012) 


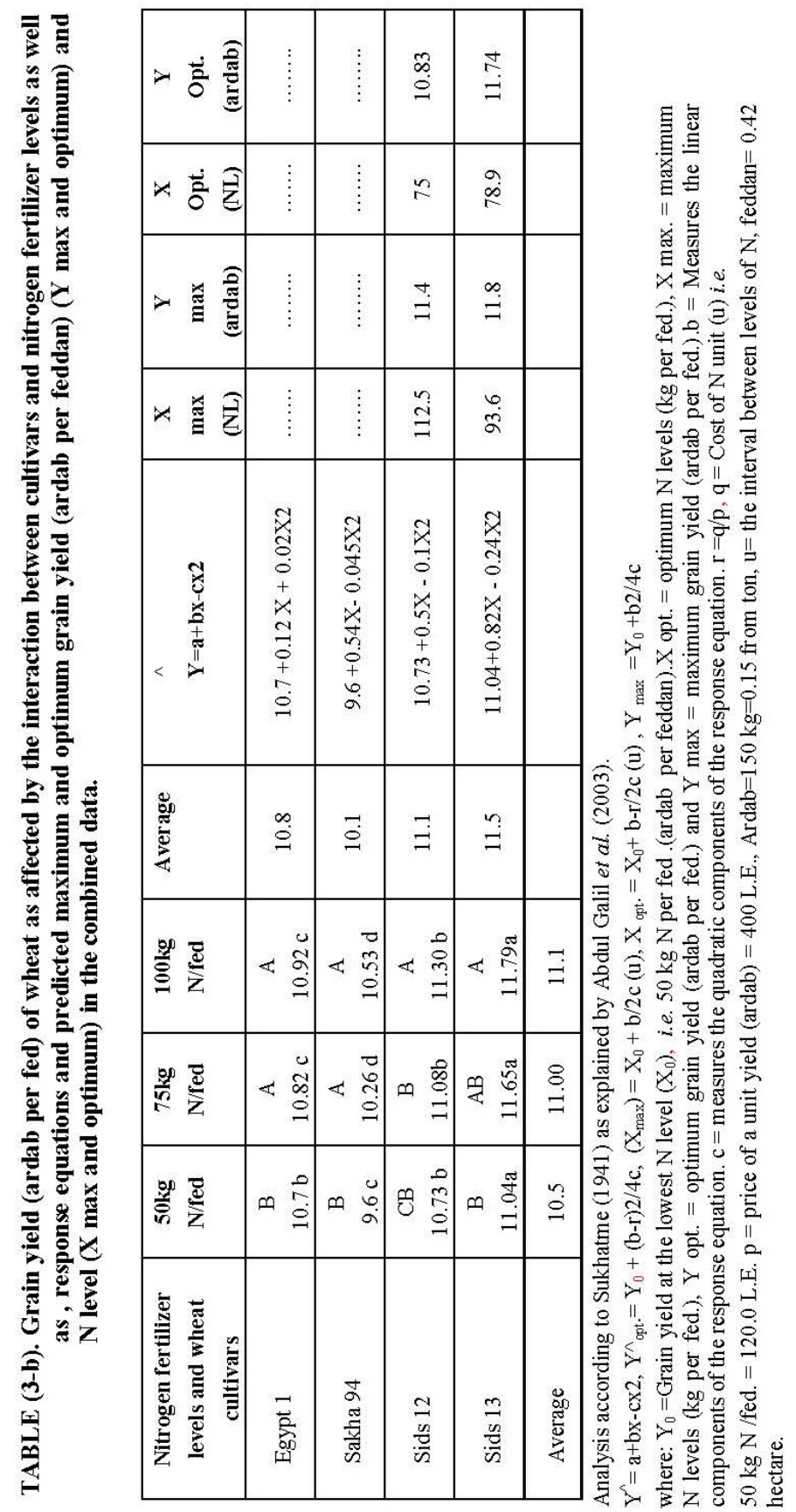

Egypt. J. Agron. 34, No. 1 (2012) 


\section{Conclusion}

Wheat cultivars Sids 13 followed by Sids 12 with the highest dose of N (100 kg N per fed.) exceeded those of Egypt 1 and Sakha 94 . This is expected when Sids 13 followed by Sids 12 gave the highest values of spike length (9.66 and $9.66 \mathrm{~cm}$ ), number of spikelets per spike (16.53 and 15.78), number of grains per spike (39.67 and 39.00), grain weight per spike (2.13 and $2.00 \mathrm{~g}$ ) 1000-grain weight (39.60 and $38.01 \mathrm{~g}$ ) as well as grain yield (11.49 and 11.04 ardab per fed for Sids 13 followed by Sids 12 ,respectively ) than those receiving 50 or $75 \mathrm{~kg}$ $\mathrm{N} /$ fed, whereas, the lowest values $(8.45 \mathrm{~cm}, 15.45,37.37,1.77 \mathrm{~g}, 36.88 \mathrm{~g}$ and 10.13 ardab per fed. for previous traits, respectively) were achieved by planting Sakha 94 and fertilized with the $1^{s t}$ dose of $50 \mathrm{~kg} \mathrm{~N} / \mathrm{fed}$, respectively. The yield could have been maximized to 11.4 and 11.8 ardab per fed due to predicted $\mathrm{N}$ addition of 112.5 and $93.6 \mathrm{~kg} \mathrm{~N}$ per fed for Sids 12 followed by Sids 13, respectively. The results, further indicated that, optimum yields were 10.83 and 11.74 ardab per fed could be obtained when 75 and $78.9 \mathrm{~kg} \mathrm{~N}$ per fed were added for Sids 12 followed by Sids 13 in respective order.

\section{References}

Abd El-Hmeed, I.M. (2005) Response of two newly released bread wheat cultivars to different nitrogen and phosphorus fertilizer levels. The $1^{\text {st }}$ Sci. Conf. Cereal Crops, June $20^{\text {th }}, 21^{s t}, 2005$ (Alexandria).

Abd El-Hmeed, I.M. and Omar, A.E. (2006) Response of bread wheat to some fertilization treatments. The $31^{\text {st }}$ International Conference for Statistics, Computer Science and its Applications 1- 6 April .

Abdul Galil, A.A., Basha, H.A., Mowafy, S.A.E. and Ahmed, Seham M.M. (2003) Effect of phosphorus addition on the response of four wheat cultivars to $\mathrm{N}$ fertilization level under sandy soil conditions. Minufiya J. Agric. Res. 28 (1), 1 - 22.

Ahmed, Seham M.M., Abdul Galil, A.A., Basha, H.A. and Mowafy, S.A.E. (2009) Response of wheat to fertilization under sandy soil conditions. Zagazig, J. Agric. Res. 36 (4), 1045-1067.

Amin, E.H.M., Ibrahim, A.A., Saleh, M.E. and Ali, A.G.A. (2010) Response of wheat cultivars to varying time of $\mathrm{N}$-application, planting densities and sowing date. Zagazig, J. Agric. Res. 37 (4), 803 - 828.

Ashmawy, F. and Abo-Warda, A.M.A. (2002) Response of some wheat cultivars to different seeding rates and nitrogen fertilization levels in sandy soil . Egypt. J. Appl. Sci. 17 (10), 136-157.

Duncan, B.D. (1955) Multiple range and multiple F test. Biometrics, 11, 1-42.

El-Murshedy, W.A. (2008) Effect of skipping one irrigation at different developmental stages of five bread wheat cultivars. J. Agric. Res., Kafer El-Sheikh Univ. 34 (1), 25-42. 
El-Sawi, S.A., Khaled, M.A. and Seleem, S.A. (2006) Effect of splitting fertilization on bread wheat productivity. J. Agric. Sci., Mansoura Univ. 31 (10), 6129 - 6142.

FAO (2007)Wheat production prospects," Food Out look' November, Economic and Social Dept.

Gafar, N.A. (2007) Response of some bread wheat varieties grown under different levels of planting density and nitrogen fertilizer. Minufiya J. Agric. Res. 32 (1), 165 - 183.

Hassan, A.I., Moselhy, M.M. and Abd El-Mabood, Sh. M. (2002) Evaluation of some wheat cultivars under two levels of irrigation water salinity in calcareous soils, South Sinai . Zagazig J. Agric. Res. 29 (1), 1-15.

Mohamed, S.E.A., El-Shewy, A.A. and Mahfouz, H. (2001) Effect of organic and inorganic fertilizers on growth, yield, chemical constituents and anatomical structure of wheat plants (Triticum aestivum L.) . Egypt. J. Appl. Sci. 16 (4), 124-141.

Ramadan, A.R. and Awaad, S.S. (2008) Response of yield and yield attributes of some bread wheat varieties to irrigation levels and seeding rate under old land conditions. $J$. Agric. Sci., Mansoura Univ. 33 (7), 4717 - 4737.

Saleh, M.E. (2003) Effect of level and splitting nitrogen on the yield potentially of Sids 1 wheat cultivar. Zagazig J. Agric. Res. 30 (4), 1169- 1188.

Shaaban, S.M. (2006) Effect of organic and inorganic nitrogen fertilizer on wheat plant under water regime. Journal of Applied Science Research, 2 (10), 650 - 656.

Snedecor, G.W. and Cochran, W.G. (1981) "Statistical Methods". $7^{\text {th }}$ ed. Iowa State, Univ. Press, Ames, Iowa, U.S.A.

Steel, R.G.D. and Torrie, J.H. (1980) "Principles and Procedures of Statistics .A Biometrical Approach" $2^{\text {nd }}$ ed. Mac Graw Hill Book Company, New York .

Sukhatme, P.V. (1941) Economics of manuring. Indian, J. Agric. Sci. 9, 325-337.

Tabl, M.A. , Omar, A.M., El-Sheref, E. and Koriem, M.A. (2005) Effect of seeding rates and nitrogen levels on two wheat cultivars. Alex. J. Agric. Res. 50 (2B), 87 - 95.

Weber, E.A., Graff, S., Koller, W.D., Hermann, W., Markt, N. and Claupein, W. (2008) Impact of nitrogen amount and timing on the potential of acrylamide formation in winter wheat (Triticum aestivum L.). Field Crop Research, 106, 44 - 52.

Zeidan, E.M., El-Khawaga, A.A., Bashha, H.A. and Abd El-Hameed, I.M. (2005) Improvement of wheat productivity in newly reclaimed soil in Egypt. Annals Universitatis Mariae Curie-Sklodowska Lublin- Polonia, Vol. 1X, Sec. ed. 60, pp. 113-121.

Zeidan, E.M., Abd El- Hameed, I.M., Bassiouny, A.H. and Waly, A.A. (2009) Effect of irrigation intervals, nitrogen and organic fertilization on yield, yield attributes and crude protein content of some wheat cultivars under newly reclaimed saline soil conditions. $4^{\text {th }}$ Conferences on Recent Technologies in Agriculture, Faculty of Agric., Cairo Univ., Egypt.

(Received 5/3/2012; accepted 10/6/2012) 
RESPONSE OF FOUR NEW BREAD WHEAT (TRITICUM AESTIVUM L.)...

استجابة أربعة أصناف حليثة لقمح الخبز لمعدلات السماد النيتروجينى تحت نظام الري بالرش بالرئر اضعي الرملية

قسم المحاصيل محمد عبدالحميل - كلية الزراعة - جامعة الزقازيق - الثرقية - مصر.

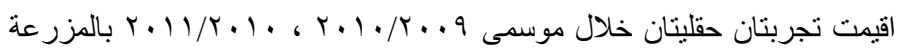

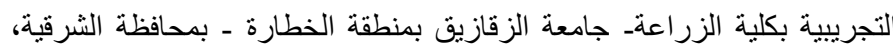

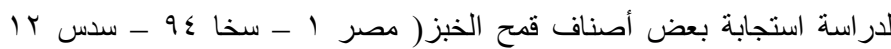

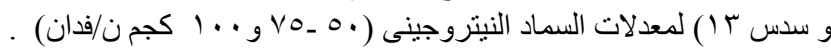

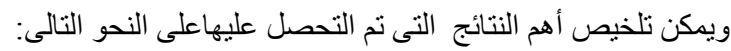

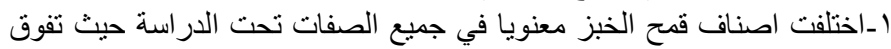

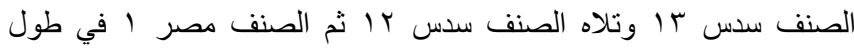

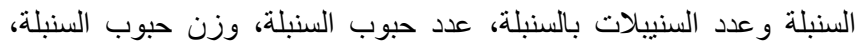

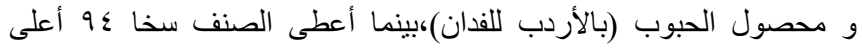

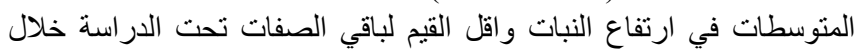

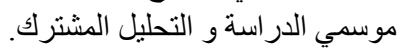

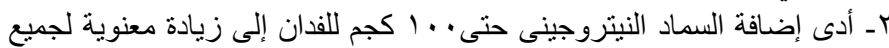

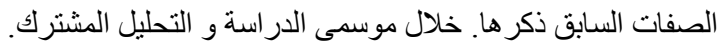

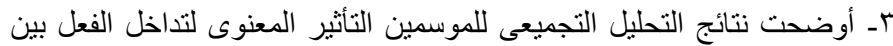

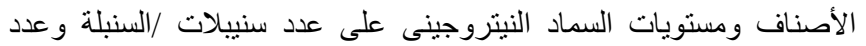

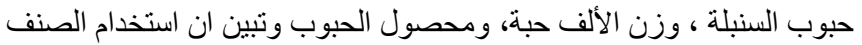

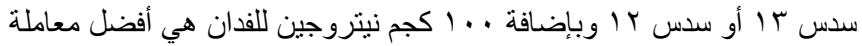

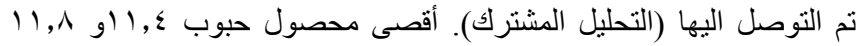

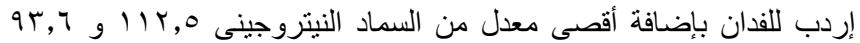

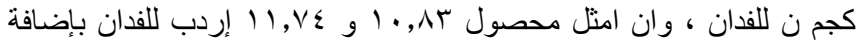

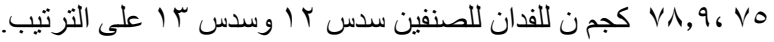

